\title{
FAKTOR-FAKTOR YANG MEMPENGARUHI PENGUNGKAPAN TANGGUNG JAWAB SOSIAL PERUSAHAAN
}

\author{
Ike Putri Wandriani \\ Program Studi Magister Manajemen Universitas Tarumanagara \\ ikeeputri@gmail.com
}

Masuk : 23-11-2017, revisi : 21-12-2017 diterima untuk diterbitkan : 21-12-2017

\begin{abstract}
The purpose of this research is to provide empirical evidence whether firm size, profitability, size of audit firm, leverage, net profit margin, and liquidity have influence to corporate social responsibility disclosure. This research used 60 samples of companies in the manufacturing sector that had been listed at the Indonesian Stock Exchange, within period from 2011 until 2013. Sample were obtained by purposive sampling method. Data were analyzed using multiple regression method. The result of this research showed that firm size, leverage, and net profit margin had influence toward corporate social responsibility disclosure. But in the contrary, profitability, size of audit firm, andliquidity had no influence toward corporate social responsibility disclosure.
\end{abstract}

Keywords: Corporate Social Responsibility Disclosure, Firm Size, Profitability, Size of Audit Firm, Leverage, Net Profit Margin, Liquidity

\section{PENDAHULUAN}

Setiap perusahaan pasti menginginkan perolehan laba bagi perusahaanya. Oleh karena itu perusahaan ingin membuat citra yang baik untuk masyarakat dengan memperhatikan lingkunganya atau tanggung jawab sosialnya yang disebut dengan CSR (Corporate Social Responsibility). Menurut Roziani dan Sofie (2010) sejarah perkembangan akuntansi semakin berkembang mengikuti jaman dan diwarnai adanya revolusi industri. Revolusi industri merupakan fase perkembangan akuntansi manajemen yang menyebabkan pelaporan akuntansi lebih ditekankan dan diperhatikan kepada akuntansi manajemen yang berhubungan dengan pertanggungjawaban terhadap pemilik modal. Pemilik modal harus ditekankan agar menjadi tujuan dan perhatian pertama perusahaan untuk dapat memaksimalkan profit.

Perusahaan memerlukan tata kelola perusahaan yang baik untuk mencapai tujuan yang maksimal dan menghasilkan citra yang baik dihadapan masyarakat. Perusahaan akan mengeluarkan sejumlah biaya untuk melaksanakan kegiatan tanggung jawab sosialnya sehingga mengurangi pendapatan dalam perusahaan. Tetapi seiring berjalannya waktu perusahaan yang melaksanakan tanggung jawab sosial akan menghasilkan loyalitas konsumen yang lebih besar terutama pada hal produk-produk yang bersifat ramah lingkungan. Ketika bisnis global saat ini tidak dapat dihindari maka dituntut untuk merealisasikan prinsip-prinsip tentang transparasi, akuntabilitas, dan good governance.

\section{KERANGKA TEORITIS DAN PENGEMBANGAN HIPOTESIS Teori Stakeholder}

Menurut Nur dan Priantinah (2012) teori stakeholder adalah komitmen berkelanjutan dari perusahaan yang berjalan secara etis dan memiliki kontribusi terhadap pembangunan untuk meningkatkan kualitas hidup tenaga kerja dan komunitas serta masyarakat. Perusahaan bukanlah entitas yang hanya beroperasi untuk kepentingannya sendiri namun harus memberikan manfaat bagi stakeholders-nya (shareholders, kreditor, konsumen, supplier, pemerintah, masyarakat, analis dan pihak lain). Stakeholder dan organisasi saling mempengaruhi, hal ini dapat dilihat dari hubungan sosial keduanya yang berbentuk responsibilitas. 


\section{Teori Legitimasi}

Teori legitimasi memberikan alasan yang logis tentang legitimasi organisasi dimana pengaruh masyarakat luas dapat menentukan alokasi sumber keuangan dan sumber ekonomi lainya. Suatu organisasi mungkin menerapkan 4 strategi legitimasi keetika menghadapi ancaman legitimasi dan menghadapi kegagalan kinerja perusahaan seperti kecelakaan yang serius atau skandal keuangan organisasi mungkin:

1. Mencoba untuk membidik pemegang saham tentang tujuan organisasi untuk meningkatkan kinerjanya.

2. Mencoba untuk merubah persis pemegang saham terhadap suatu kejadian (tetapi tidak merubah kinerja organisasi).

3. Mengalihkan perhatian dari masalah yang menjadi perhatian (mengkonsentrasikan terhadap beberapa aktivitas positif yang tidak berhubungan dengan kegagalankegagalan).

4. Mencoba utuk merubah external tentang kinerjanya.

\section{Teori Kontrak Sosial}

Teori ini muncul karena adanya interelasi dalam kehidupan sosial masyarakat, agar terjadi keselarasan, keserasian, dan keseimbangan, termasuk dalam lingkungan. Kontrak sosial dibangun dan dikembangkan untuk menjelaskan hubungan antara perusahaan terhadap masyarakat. Perusahaan memiliki kewajiban pada masyarakat untuk memberikan manfaat bagi masyarakat akan selalu mematuhi aturan dan norma yang berlaku sehingga kegiatan perusahaan dipandang legitimate. Dalam konteks perusahaan dan stakeholder, kontrak sosial mengisyaratkan bahwa perusahaan seharusnya berusaha untuk memastikan bahwa operasinya harus congruence dengan ekspektasi masyarakat sehingga dapat disebut legitimasi. Hal ini sejalan dengan konsep legitimacy theory bahwa legitimasi dapat diperoleh jika terdapat kesesuaian antara keberadaan perusahaan tidak menggangu atau sesuai (congruence) dengan eksistensi sistim nilai yang ada dalam masyarakat dan lingkungan.

\section{Penelitian Terdahulu}

\section{Pengaruh Ukuran Perusahaan terhadap Pengungkapan Tanggung Jawab Sosial Perusahaan}

Penelitian Wijaya (2012) menyatakan dari hasil penelitianya terdapat hubungan yang positif antara ukuran perusahaan terhadap pengungkapan tanggung jawab sosial perusahaan. Hipotesis yang diajukan sebagai berikut:

$\mathrm{H}_{\mathrm{a} 1}$ : Ukuran perusahaan berpengaruh terhadap pengungkapan tanggung jawab sosial perusahaan.

\section{Pengaruh Profitabilitas terhadap Pengungkapan Tanggung Jawab Sosial Perusahaan}

Penelitian Wijaya (2012) yang dilakukan juga menunjukkan bahwa tidak ada hubungan antara profitabilitas terhadap pengungkapan tanggung jawab sosial perusahaan memberikan pengaruh negatif. Hipotesis yang diajukan sebagai berikut:

$\mathrm{H}_{\mathrm{a} 2}$ : Profitabilitas berpengaruh terhadap pengungkapan tanggung jawab sosial perusahaan.

Pengaruh Ukuran Perusahaan Audit terhadap Pengungkapan Tanggung Jawab Sosial Perusahaan

Hasil penelitian yang dilakukan oleh Uwuigbe dan Egbide (2012) adalah tidak ada hubungan antara perusahaan ukuran perusahaan audit dan tingkat pengungkapan tanggung jawab sosial perusahaan di antara perusahaan yang dipilih. Hipotesis yang diajukan sebagai berikut:

$\mathrm{H}_{\mathrm{a} 3}$ : Ukuran kantor akuntan publik berpengaruh terhadap pengungkapan tanggung jawab sosial perusahaan.

\section{Pengaruh Leverage terhadap Pengungkapan Tanggung Jawab Sosial Perusahaan}

Dalam penelitian yang dilakukan oleh Wijaya (2012) menunjukan adanya hubungan antara leverage terhadap pengungkapan tanggung jawab sosial perusahaan yang memberikan pengaruh positif. Hipotesis yang diajukan sebagai berikut: 
$\mathrm{H}_{\mathrm{a} 4}$ : Leverage berpengaruh terhadap pengungkapan tanggung jawab sosial perusahaan.

Pengaruh Net Profit Margin terhadap Pengungkapan Tanggung Jawab Sosial Perusahaan

Pada penelitian yang dilakukan oleh Utami pada menunjukan bahwa adanya pengaruh antara pengaruh laba bersih terhadap pengungkapan tanggung jawab sosial perusahaan yang memberikan pengaruh positif. Hipotesis yang diajukan sebagai berikut:

$\mathrm{H}_{\mathrm{a} 5}$ : Net profit margin berpengaruh terhadap pengungkapan tanggung jawab sosial perusahaan.

\section{Pengaruh Likuiditas Terhadap Pengungkapan Tanggung Jawab Sosial Perusahaan}

Laksmitanigrum dan Purwanto (2013) menunjukan adanya hubungan positif antara likuiditas dan pengungkapan tanggung jawab sosial perusahaan. Hipotesis yang diajukan sebagai berikut:

$\mathrm{H}_{\mathrm{a} 6}$ : Likuiditas berpengaruh terhadap pengungkapan tanggung jawab sosial perusahaan.

\section{METODE PENELITIAN}

\section{Obyek Penelitian}

Objek penelitian yang digunakan dalam penelitian ini yaitu perusahaan manufaktur yang terdaftar di BEI periode 2011 sampai 2013. Metode pengambilan sampel yang digunakan adalah metode purposive sampling, dimana pemilihan sampel dilakukan atas dasar kesesuaian karakteristik sampel dengan kriteria-kriteria tertentu yang telah ditetapkan untuk mencapai tujuan penelitian.

\section{Definisi Operasional}

\section{Pengungkapan Tanggung Jawab Sosial Perusahaan.}

Pengungkapan tanggung jawab sosial perusahaan diukur dengan menggunakan proksi CSRD berdasarkan pada penelitian Uwuigbe (2011). Pendekatan ini pada dasarnya menggunakan pendekatan dikotomi yaitu setiap item CSR dalam instrumen penelitian diberi nilai 1 jika diungkapkan dan diberi nilai 0 jika tidak diungkapkan. Lalu skor dari setiap item dijumlahkan untuk memperoleh keseluruhan skor dalam setiap perusahaan. Skala yang digunakan adalah skala nominal. Dalam penelitian ini, variabel pengungkapan tanggung jawab sosial perusahaan (corporate social responsibility disclosures) dirumuskan sebagai berikut:

$$
\operatorname{CSRD}_{\mathrm{i}}=\sum_{i=1}^{20} d_{i}
$$

Keterangan :

$\operatorname{CSRD}_{\mathrm{i}}$ : Total Disclosure score

$d_{i}$ : Dummy Variable: $1=$ jika item i diungkapkan; $0=$ jika item i tidak diungkapkan.

I $: 1,2,3 \ldots 20$

\section{Ukuran Perusahaan}

Ukuran perusahaan merupakan skala yang digunakan dalam menentukan besar kecilnya suatu perusahaan. Pada umunya perusahaan besar lebih banyak mengungkapkan tanggung jawab sosial dari pada perusahaan yang skala kecil. Perusahaan besar akan mengalami tekanan agar perusahaan lebih besar dan risiko-risiko yang terjadi terhadap perusahaan akan lebih besar. Pengukuran ini mengacu pada penelitian yang dilakukan oleh Uweigbe (2011). Ukuran perusahaan dirumuskan sebagai berikut:

SIZE $=\log$ (nilai buku total aset)

\section{Profitabilitas}

Profitabilitas menentukan perusahaan dimana rasio profitabilitas menghitung kemampuan perusahaan dalam mendapatkan keuntungan perusahaan. Rasio profitabilitas diukur menggunakan ROA adalah rasio laba bersih setelah pajak terhadap total aktiva, yang mengukur tingkat pengembaliaan investasi para investor. Tingkat profitabilitas dapat menunjukan seberapa baik pengelolaan manajemen perusahaan, oleh sebab itu semakin tinggi 
profitabilitas suatu perusahaan maka cenderung lebih luas pengungkapan tanggung jawab sosialnya. Pengukuran ini mengacu pada penelitian yang dilakukan oleh Uwuigbe (2011). Profitabilitas dirumuskan sebagai berikut:

ROA $=\frac{\text { Laba bersih setelah pajak }}{\text { Total aktiva }}$

\section{Ukuran Kantor Akuntan Publik (UKAP)}

Ukuran perusahaan audit dalam penelitian ini diukur menggunakan variabel dummy yaitu dengan memberikan nilai 1 untuk auditor affiliated with the big four auditing firms, dan memberikan nilai 0 untuk auditor non affiliated with the big four auditing firms. Pengukuran ini mengacu pada penelitian yang dilakukan oleh Uweigbe (2011).

\section{Leverage}

Leverage merupakan suatu alat penting pengukuran dalam efektifitas penggunaan utang perusahaan yang digambarkan untuk melihat sejauh mana aset perusahaan dibiayai oleh hutang dibandingkan dengan ekuitas yang disebut dengan DER. Pengukuran ini mengacu pada penelitian yang dilakukan oleh Sari (2012). Leverage yang dirumuskan sebagai berikut:

\section{Net Profit Margin}

$$
D E R=\frac{\text { Total Kewajiban }}{\text { ekuitas }}
$$

Net profit margin adalah rasio yang mengukur kemampuan perusahaan dalam menghasilkan net income dalam tingkat penjualan tertentu. Rasio antara net income terhadap penjualan. Net income yang dirumuskan sebagai berikut:

Net profit margin $=\frac{\text { net income }}{\text { sales }}$

\section{Likuiditas}

Likuiditas merupakan suatu alat penting pengukuran dalam menentukan kesehatan suatu perusahaan. Likuiditas diukur dengan menggunakan rasio likuiditas yaitu current ratio dimana aktiva lancar dibagi dengan kewajiban lancar. Pengukuran ini mengacu pada penelitian yang dilakukan oleh Badjuri (2011). Likuiditas yang dirumuskan sebagai berikut:

CURRENT RATIO $=\frac{\text { aktiva lancar }}{\text { kewajiban lancar }}$

\section{Metode Analisis Data}

Metoda analisis data yang digunakan dalam penelitian ini adalah menggunakan analisis regresi berganda (multiple regression analysis) dengan tingkat kesalahan atau $\alpha$ sebesar 5\%. Uji linear berganda untuk memperlihatkan hubungan antara satu variabel dependen dengan beberapa variabel independen (Ghozali 2013, 95). Berikut ini adalah model regresi linear pada penelitian ini:

$$
\mathrm{CSRD}=\beta_{0}+\beta_{1} \mathrm{UP}+\beta_{2} \mathrm{ROA}+\beta_{3} \mathrm{UKAP}+\beta_{4} \mathrm{DER}+\beta_{5} \mathrm{NPM}+\beta_{6} \mathrm{CR}+\boldsymbol{\varepsilon}
$$

\section{PENUTUP}

Penelitian ini dilakukan untuk memperoleh bukti empiris pengaruh ukuran perusahaan, profitabilitas, ukuran kantor akuntan publik, leverage, net profit margin, dan likuiditas terhadap pengungkapan tanggung jawab sosial perusahaan pada perusahaan manufaktur yang terdaftar di Bursa Efek Indonesia.

\section{DAFTAR REFRENSI}

Badjuri, A. (2011). Faktor-faktor fundamental, mekanisme corporate governance, pengungkapan corporate social responsibility (CSR) perusahaan manufaktur dan sumber daya alam di indonesia corporate governance mechanism, fundamental factors, corporate social responsibility (csr) disclosure of a natural resource and manufactuer company in indonesia. Dinamika keuangan dan perbankan, 38-54. 
Ghozali, I. \& Chariri, A. (2007). Teori Akuntansi. Semarang: Universitas Diponegoro.

Ghozali, I. (2013). Aplikasi Analisis Multivariate Dengan Program IBM SPSS 19 Update PLS Regresi. Semarang: UniversitasDiponegoro

Nur, M. \& Priantinah, D. (2012). Analisa faktor-faktor yang mempengaruhi pengungkapan corporate social responsibility di Indonesia (Studi empiris pada perusahaan berkategori high profile yang listing di bursa efek indonesia). Jurnal Nominal, 1(1), 22-34.

Roziani, S. (2010). Analisis faktor-faktor yang mempengaruhi tingkat pengungkapan sosial dalam laporan tahunan bank konvensional dan bank syariah di Indonesia. Islamic Finance \& Business Review, 5(1).

Utami, P. D. (2011). Pengaruh karakteristik perusahaan terhadap social disclosure. Jurnal Ekonomi Bisnis, 16(1).

Uwuigbe. (2011). An empirical investigation of the association beteen firms characteristics and corporate social disclosures in the nigeria financial sector. Journal of sustainable development in Africa, 13(1).

Uwuigbe, U. \& Egbide, B. C. (2012). Corporate social responsibility disclosures in Nigeria: a study of listed financial and non-financial firms. Journal of Management and Sustainability, 2(1), 160-169.

Wijaya, M. (2012). Faktor-faktor yang mempengaruhi pengungkapan tanggung jawab sosial pada perusahaan manufaktur yang terdaftar di Bursa Efek Indonesia. Jurnal Ilmiah Mahasiswa Akuntansi, 1(1). 